\title{
THE PHILOSOPHER IN THE NEWSPAPER: SERHIY KRYMSKY AS A PUBLIC INTELLECTUAL
}

\author{
Andriy Melnyk ${ }^{7}$
}

\begin{abstract}
Interactions of philosophical and journalistic spheres, mediatization of philosophy are main problems of this article. Author considers public philosophy of contemporary Ukrainian philosopher Serhiy Krymsky and determines a role of philosophical journalism in modern media discourse.

Key words: Serhiy Krymsky, philosophy, journalism, newspaper, mediatization, society, spiritualness, public intellectual, public thinker
\end{abstract}

\section{Introduction}

Serhiy Krymsky (1930-2010) was a famous Ukrainian philosopher, who in the late 90 's - early 2000's actively cooperated with the media, mainly popular newspaper "The Day" $^{2}$ - one of the few that are printed in English (as weekly digest). This cooperation was not only commenting on current events, but also a complete way of presenting his philosophy to a wider audience. There are some atypical features of Serhiy Krymsky as a public intellectual. Despite mediatization, he managed to keep his themes and style. As Pierre Bourdieu once said, academic scholar must weigh the risks to avoid becoming a hostage of media format [See: Bourdieu, 1998]. Krymsky's combination of philosophical depth with focusing on contemporary issues allowed him to create a special approach that can be called "philosophical journalism".

\section{"Philosophical journalism" and "Public philosophy": definition of concepts}

The philosophy at least since the time of Socrates claims to play a significant public role. Nineteenth century and the first half of the twentieth confirmed this trend. It is hard to overestimate the impact that had Marx's, Nietzsche's and Freud's works on various aspects of life of the Western societies. In the past century philosophers had become rulers of the minds largely due to active cooperation with the media. But for this they had to sacrifice academic style and take on the role of public intellectuals. One of the most influential French philosophers of the first half of the twentieth century, Jean- 
Paul Sartre, founded together with his associates newspaper "Liberation", which was to convey to the wider social circles the idea of "leftish" existentialism. Sartre was the incarnation of the phenomenon, which led Raymond Aron speak against it, published in 1955 his famous book "Opium of the Intellectuals". This "opium" was Marxism - or, in the broadest sense - any uncritically accepted ideology.

Regardless to Aron's fair warnings French philosophy is not getting rid of ideological bias. Moreover, ideological ties cause its active cooperation with media. In the 70's "new philosophers" appear on the French intellectual scene. Their texts resembled literary or journalistic works and were devoted to mainly important political events. Some critics of this approach expressed about the new direction rather dramatically: for example, Gilles Deleuze said that the "new philosophy" is trifling in its nature" [Энговатова 2007, p. 47]. Instead, Bernard-Henri Levy, one of the most famous representatives of this movement, calling journalism "an important arena of abstract thought" declares that "journalism - is a thought, a philosophy." In addition, he is the author of the thought which can be regarded as a slogan of "new philosophers": "I personally believe that it's time to leave the monastery to talk openly and clearly, strongly and actively throw into hell of the present, in a diabolical comedy of century" [Матиенко, 2004].

French scientist Regis Debray in his book "Intellectual Power in France" gives eloquent fact: "In the fifties, a university professor, who published in "France-Soir ", or writer, who was a guest in TV shows presented themselves as a taunt. In the eighties, those who do not do this will look a little suspicious" [Дебре, 2008, p. 110]. Sociologist Louis Pinto, who investigated the mutual influence of philosophical and media areas in France speaks about "philosophical journalism" and "media philosophers" as a result of the imposition of the principles of successful operation of mass media (such as "novelty") in academic field which lives on its own, often diametrically opposite to informational journalism practices. The scientist describes a dubious position of philosophy, which falls depending on the "fashion" and "thoughts" and believes that "expanding the role of the philosopher causes its impairment". Conditions when "mass media intervened even in such esoteric areas as philosophical production" still forced to reconsider the current concept of "philosophy" and the status of the philosopher. The author gives the example of the French intellectual Alain Finkielkraut, who received a literary education, but made no contribution to the so-called "philosophical questions" (knowledge, objectivity, truth, language, etc.). However, in public discourse, he was seriously promoted as philosopher.

According to L. Pinto, "endless multicultural debate about "zeitgeist" provides media philosophers not only to the status of a special participant who can interpret, ask questions, act as judges..." That's why the "new philosophy" feels in the French media discourse so confident. Thus, the "philosophical journalism is par excellence the a cultural formula whereby intermediaries, people who cross the borders and carry out conversions, whether journalists, writers or university professors, contribute to making the free circulation in the intellectual field collectively acceptable" [Пэнто, 1996, p. 37]. 
The active cooperation of the French media and academics begin in 196070 's, when a number of influential newspapers ("Liberation", "Le Monde", "Le Nouvel Observateur" and others) started to cooperate with specialists of different areas of knowledge, philosophers and writers. Ultimately, media support contributed to the emergence of the "new philosophers", and it marked the blurring of boundaries between closed academic and public spheres.

Detailed analysis of philosophical journalism made by L. Pinto shows an ambiguous situation in relations of philosophy and journalism. On the one hand, philosophy becomes more accessible, it opens for a wider range of readers, its intervention not limited to some specific defined area, and philosopher often delivers a political slogans (an examples of B.-A. Levi and A. Gluksmann are quite eloquent). On the other, there is a risk of simplification, blurring of boundaries between real science and pseudo philosophy. Of course, opponents of the "new philosophers" refer to this trend rather critically, because academic scientists are sometimes reluctant to leave the boundaries of their cabinets. However, mediatization of public sphere and expanding of boundaries of the publicity today are too obvious to not respond to them. Today we can say with certainty that the mass media "occupied" public sphere or replaced it by themselves. Scientists are saying that the scope of the media is the "first nature" or "the first reality", which largely shapes our view of the world. According to the German neoconservative thinker Gerd-Klaus Kaltenbrunner, the media are not only the technical, social, psychological and political problem, but above all the ontological problem. They are therefore only able to display, veil and distort reality, because they have the ability to define it. What we perceive as reality is not simply given, but the result of media [as cited in Ермоленко, 2008, р. 29].

The example of French intellectuals is perhaps the best illustration of mediatization of philosophy and the academic sphere in general. But this is not an exceptional example of such situation. Modern American philosopher, a professor at Harvard, Michael Sandel uses the term "public philosophy". He describes a public philosophy in two dimensions: the first is to "find in the political and legal controversies of our day an occasion for philosophy", the second is to "bring moral and political philosophy to bear on contemporary public discourse" [Sandel, 2005, p. 5]. At about the same sense, the term "public philosophy" used by other American scientists - James Tully and Richard Posner [See Tully, 2008; Posner, 2003]. So we can say that both terms, "philosophical journalism" and "public philosophy", are describing the same phenomenon from different perspectives. Its essence lies in the fact that intelligent life is affected by mediatization, though only where the media and academic institutions enjoy relatively free development.

\section{The agenda of Serhiy Krymsky's public philosophy}

Serhiy Krymsky's understanding of the philosophy is quite unusual given to his status of academic scientist. "Philosophy - is not an abstract thing. This is the solution 
of the problems encountered in real life ", he said in an interview. When answering the follow-up question whether philosophy can be reduced in this case exclusively to applied problems and instructions à la Dale Carnegie, he replied: "It is not just about practical problems, but the fundamental problems that we involuntarily, subconsciously decide" [Верлока, 2006, р. 141]. Describing his philosophy (at any rate in the later period), S. Krymsky sometimes resorted to rather ambiguous comparisons:

I often tell my colleagues from the Institute of Philosophy: here we are at Volodymyrska Hirka (Prince Volodymyr's Hill, a public park in Kyiv) where many people are walking. Come out to them and start to lecture on philosophical categories, the processes of cognition. And people will consider you as an idiot. And if I get to lecture, I'll start talking about the meaning of life, about human's fate, about love, about the dramatic struggle between good and evil. Do you think people will listen to me? There will gather a lot of people, I know for sure! It's not so much a question of language, as a matter of topics, and topics prompt language and style" [Верлока, 2006, p. 140].

These words describe the very peculiar nature of S. Krymsky's public philosophy. Andre Glucksmann, a representative of the "nouvelle philosophie", begins his book "Dostoevsky in Manhattan" with an epigraph by Stendhal: "My philosophy depends on the time in which I write." The same words can characterize the philosophy of Serhiy Krymsky. But it is necessary to clarify that his newspaper articles are not pure journalism, as it often happens with the "nouveaux philosophes". Cooperating with "The Day", he defined landmarks for newspapers as well. In his opinion,

the newspaper as an intellectual body of communication and social activity should not be limited only to simple informing. We begin to feel that its mission is to be the herald of truth. This means that the newspaper transmits not only the facts but also opinions, not only information but also the position of its evaluation, serves as an analyst of imputation and disclosure of problematic situations. If newspaper serving to heralding, it is involved in broadcasting information from the world as it is, to the world as it should be [Кримський, 2002].

Defining goals of newspapers as well, he also describes his role as a public thinker. This somewhat resembles the step that did Immanuel Kant in the XVIII century, when published treatise "Answering the Question: What Is Enlightenment?" In his work, he, in addition to the characteristics of the Enlightenment, implicitly defined the proper place of the public intellectual and pointed out what qualities he should have.

Hence, go beyond the routine - this is the task of public philosopher who addresses to the public on the pages of daily newspapers. S. Krymsky did it mostly through interviews or "updated monologues" (as it defined the editorial office of "The Day"). In our view, it is advantageous genres for academic intellectual, because he is not forced to adapt his philosophy to the format of newspaper articles. Although he had to go to certain concessions, refusing excessive terminology and scientific style. Among other 
tasks set by S. Krymsky for newspapers, there is one that explains why he did not become "pure" journalist: "Like the theater, the newspaper should "create" audience, readership and shape them" [Махун, 2001]. This means that the public thinker on the pages of this kind of newspaper should not turn into a showman or a commentator on small current events, while he himself is able to determine the time and occasion of his public appeal. And most importantly, the content of his message is not dependent on conditions and conjuncture. The philosopher himself determines what is relevant.

Unlike many experts, who assess or comment on topics that are offered by the newspaper, S. Krymsky in his "updated monologues" appears with his own agenda. It can be viewed as a privilege, because now not every public intellectual can afford to apply to the public with the message that is deemed irrelevant or alternative. In this particular case, we see the destruction of the monopoly of mass media on the definition of relevant topics and "media-genic" behavior. However, this case is rather exceptional. The name of one of the interviews of S. Krymsky supposedly alludes to this: "If a wise man is in a minority?" Referring to the example of Plato's Socrates in this interview, he recalls that the will of the majority is not always good, especially when it suppresses objection of sage. Thus S. Krymsky recognized and at the same time warned that public philosopher can be lonely and unpopular. But it's voluntary and informed choices of those who do not want to adapt to the requirements of the media format.

S. Krymsly's view on this issue reminds us of the famous Ukrainian philosopher of the 18th century Hryhorii Skovoroda, who also faced a dilemma of popularity and opportunism. He opted for the escape from the world, and on his tombstone carved an epitaph: "The world tried to catch me, but hadn't succeeded." Obviously, this type of philosopher is unlikely to be able to work with modern media. But he was an important thinker for S. Krymsky, who wrote a book about him, which was for a long time banned in the Soviet times. In a newspaper article on Skovoroda, "Philosopher Whom the World Failed to Catch", Krymsky described the role of the philosopher in the Ukrainian tradition in such way:

Skovoroda's work is of tremendous importance difficult to overestimate in the history of Ukrainian spirituality and European mentality as such. He was one of the first in modern European civilization to assert the phenomenon of wisdom, which after Ancient Greece and Rome had been effaced by the all-embracing idea of a rational and mechanistic interpretation of all things extant and of regarding truth as something separate from good and evil. In his lecture, the philosopher put forward the idea that existence itself is filled with sense, that is, life is originally full of wisdom, enlightenment, hope, and harmony, which the Ukrainian mentality used as an ideational basis to counter chaos, "the external darkness" of the hostile forces of evil, foreign oppression, and invasions [Krymsky, 2001].

Ideas of wisdom and spirituality, which are mentioned in the passage above, are a crucial component of S. Krymsky's public philosophy. One of his most famous articles devoted to the idea of spirituality. In his public lecture which was published as a newspaper article, "The Principles of Spirituality in the 21 st Century", he attempts to 
consider the concept of spirituality unconventionally, rejecting clichés and stereotypes. It is necessary to take into account that the term "spirituality" has a very mixed reputation nowadays. This is primarily due to the abuses by this concept, giving it an abstract meaning. The word "spirituality" was very popular in the 80's and 90's of the last century, but today it is often used in post-soviet media discourse ironically and even disparagingly. Serhiy Krymsky tries to give it a new meaning and a "new breath".

Philosopher relates spirituality primarily to the efforts of personality who is engaged in self-creation. He provides a list of individuals who can be called a kind of example for those who want to become an integral personality (or monad-person, as he calls them). Among them - Mahatma Gandhi, Martin Luther King, Mother Maria Skobtsova, Andrei Sakharov, Volodymyr Korolenko, Mykhailo Hrushevsky. Their examples are an illustration of the thesis that sometimes a person may play not lesser role than mass political movement. In order to become a person, it's not necessarily to go into politics or become a public figure. But it means to work hard to learn more about ourselves, because, as the philosopher argues,

according to psychological studies, only $5 \%$ of people know something about ourselves. So spirituality characterizes the way to oneself. The path that person passes all his entire life. (...) Spirituality - it is always valuable housebuilding of personality. This is a never-ending way to shape one's inner world, which allows a person does not depend entirely on the context of external life, in other words, to remain identical to oneself [Махун \& Сюндюков, 2002].

Considering spirituality in ethical perspective, S. Krymsky establishes a distinction between spirituality and ideology, calling the latter entirely in the spirit of Marxism a class-dependent consciousness. The philosopher argues that spirituality - is not only ideas, but above all a way of life. Referring to the experience of literature, he cites a replica of the character from the novel "Life and Fate" by Vasily Grossman. Being in a German concentration camp, he said to his friend:

I am against the idea of good, because Hitler could use the idea of good to justify this camp, for "improving the race". But I am in favor of goodness. Because goodness is a human quality, it is impossible to distort it in this way [as cited in Махун \& Сюндюков, 2002].

Thus, if spirituality is not implemented in practice, it is not genuine; it's rather "rhetorical spirituality", which is used as a speculative argument in political discourse. Spirituality should be implemented in deeds, and philosopher calls the main problem of our time the ability to practice spirituality. In his view, the ideas are not a major deficiency of our time, but the human qualities.

As a public philosopher Serhiy Krymsky can hardly be called a theorist of spirituality, he is more likely its interpreter for the general public. No wonder that his articles are filled with numerous illustrative examples, including from the literature, rather than abstract reasoning. He's not afraid to give life stories as illustrations for general conclusions to be understandable to the common reader. As an example, we present an excerpt from the already mentioned article, "The Principles of Spirituality in the 21 st Century": 
A Polish priest - it was not that long ago - came to Paris and found himself near the bridge, which is called "Suicide Bridge". He saw a young man who obviously planned to jump out of it. The priest came closer to him and said: "I will not have to persuade you not to do this step. It's your business, if you have decided, then rush. But you have money in your pocket, and there is a beggar on the street corner. You don't need the money, so go and give them to him." The young man went away and never returned... [Махун \& Сюндюков, 2002].

This passage is intended to illustrate how spirituality "operates", namely as a service to others.

Explaining the essence of wisdom in a practical perspective, S. Krymsky speaks at the newspaper as a "sage". The role of "sage" in contrast to the role of "expert" provides no sectoral expertise in terms of specialization, but consideration of the fundamental issues in a broad cultural context involving practical daily experience. S. Krymsky's positiononig as a "sage" can be easily traced at the level of titles of his articles. For example, one of it called "Serhiy Krymsky on the art of living" [Сюндюков, 2007]. Of course, "art of living" can not be a matter of highly specialized expertise, because it rather belongs to the "competence" of sage. Another illustration of the role of the "sage" is the article "Serhiy Krymsky's monologues about wisdom and life" [Makhun, 2001], in which the philosopher discusses the concepts mentioned in the title at the Saint Sophia's Cathedral. Decoding the complex symbolism of the cathedral, he at the same time talks about the peculiarities of Ukrainian culture and mentality. Thus, in his interpretation the Cathedral becomes not only a religious building of its history, but the embodiment of wisdom that helped Ukrainian nation withstands, and which should be guided today.

Spirituality and wisdom was not the only subjects that S. Krymsky as a public philosopher covered. But they were a kind of universal prism through which he saw other problems. The philosopher has spoken repeatedly with comments on current events. In March 2003, he published an anxiety-filled article on the war in Iraq. Article's title "Third Millennium: Shattered Illusions" showed that the author was interested in the broader historical context, not only short-term effects of the newly launched war. Even more, he was interested in biblical context of the military operation, pointing that

the essence of current developments in Iraq prompts one to infer that the historical drama of the US military action unfolds in a space marked by the Scriptures using the semantics of the Fall and the world dividing into good and evil. To use biblical metaphors, what happened between the Tigris and Euphrates was a temptation by the Devil of humans, attracting them to the forbidden fruit on the Tree of Knowledge, for which transgression man was punished and made mortal [Krymsky, 2003].

This passage is a vivid illustration of the author's style and way of thinking, the essence of which is to teach the reader to evaluate current events involving a wide range of arguments. It should be noted that the main focus of this article was not so much a condemnation of US actions as rejection of war as such, as a way of resolving 
contradictions. Therefore, this article may be attributed to the great tradition of antiwar pamphlets, which includes Erasmus, Immanuel Kant, Jean-Jacques Rousseau and others. S. Krymsky entirely in keeping with this tradition considers current historical events as part of the History (exactly with a capital). Thus, his comment does not apply to the events of March 2003, which is rather an occasion. Generally, sage comments regarding much longer chronological periods, such as "twenty-first century", "new millennium" or general intervals of indeterminate duration - "modernity" or "future". The issue of verification of these "diagnoses" is rather ambiguous because of omnitude, which "sage" allows to himself. But it's a necessary part of his role, because the audience expects from him long-term predictions or even prophecies, rather than short-term forecasts.

Few years ago after reading the list of the most influential thinkers in the world according to "Foreign Police" magazine, Gideon Rachman, "Financial Times" columnist, asked: "Where have all the thinkers gone?" His question was caused by the fact that the list of the magazine contains of more doers than thinkers:

In joint first place come Bill Gates and Warren Buffett for their philanthropic efforts. Then come the likes of Barack Obama (at number three), Celso Amorim, the Brazilian foreign minister (sixth), and David Petraeus, the American general and also, apparently, the world's eighth most significant thinker. It is not until you get down to number 12 on the list that you find somebody who is more famous for thinking than doing - Nouriel Roubini, the economist [Rachman, 2011].

In last year's ranking trend continued, and doers and activists again took first places (http://globalthinkers.foreignpolicy.com/). Answering his own question and comparing today's participants of the rate with great thinkers of the past, such as Darwin, Marx, Dickens, Tolstoy, Einstein, Keynes, TS Eliot and others, Rachman finds few explanations. First is that we might need a certain temporal distance in order to judge greatness. Second is that familiarity breeds contempt and we can't recognize the greatness of some thinkers because they are still in our midst. And finally thirdly, Racman states the fact that the nature of intellectual life has changed and become more democratic. Therefore, the author concludes:

In the modern world more people have access to knowledge and the ability to publish. The internet also makes collaboration much easier and modern universities promote specialization. So it could be that the way that knowledge advances these days is through networks of specialists working together, across the globe - rather than through a single, towering intellect pulling together a great theory in the reading room of the British Museum. It is a less romantic idea - but, perhaps, it is more efficient [Rachman, 2011].

In light of these considerations, it is worth to recall S. Krymsky's opinion that today human qualities no less urgent than ideas. This statement may be a good answer to the Gideon Rachman's question why there are more activists than thinkers in annual Foreign Policy's ranking of public intellectuals. It sounds rather paradoxically, but as a public thinker S. Krymsky prefers actions over ideas. Thus, it might be a statement of his own secondariness. But we should remember that for academic intellectual 
involvement in media sphere and becoming a public thinker is already an action.

\section{Conclusions}

S. Krymsky was one of the few professional philosophers who received the most prestigious Ukrainian award, Shevchenko National Prize, which is awarded mainly writers and other artists. He was honored by this award in 2003 for the books "Request of Philosophical Meanings" [Кримський, 2003] and "Philosophy as a Way of Humanity and Hope" [Крымский, 2000]. It was certainly a recognition of his outstanding role as a public thinker, and also the fact that philosophy should play a more prominent role in life of society. Thereafter he even was invited several times on TV, but this does not become a good tradition.

On the one hand, Serhiy Krymsky's cooperation with "The Day" newspaper was some loss to him as a philosopher, and achievement as for public intellectual, on the other. Many thinkers made concessions to the publicness, at least from the time of Erasmus, who, according to Johan Huizinga, was one of the first European intellectuals who faced the challenge of books printing. Serhiy Krymsky's philosophical journalism (or public philosophy) can be a good model of how the philosopher, who works with the media, is able to combine the depth of his profession with the challenges of time and service to the society.

\section{References}

BOURDIEU, P. (1998). On Television. New York: The New Press.

Krymsky, S. (2001). Philosopher Whom the World Failed to Catch. The Day, №7.

Krymsky, S. (2003). Third Millennium: Shattered Illusions. The Day, № 10, 25 March.

Makhun, S. (2001). Serhiy Krymsky's monologues about wisdom and life. The Day, № 14, 15 May.

Sandel, M. J. (2005). Public Philosophy: Essays on Morality in Politics. Cambridge, Massachusetts: Harvard University Press.

Posner, R. (2003). Public Intellectuals: A Study of Decline. Cambridge, Massachusetts: Harvard University Press.

Rachman, G. (2011). Where have all the thinkers gone? The Financial Times, 25 Jan.

Tully, J. (2008). Public Philosophy in a New Key: Volume 1, Democracy and Civic Freedom. Cambridge, UK: Cambridge University Press.

Верлока, В. (2006). Філософія як стиль життя. Інтерв'ю із Сергієм Борисовичем Кримським. Дух і літера, № 15-16, 138-160.

Дебре, Р. (2008). Інтелектуальна влада у Франції. Київ: Дух і Літера.

Ермоленко, А. (2008). Публичный дискурс как фактор интеграции в современном обществе, In M. Соколова (ed.), В. Фурса (ed.) Постсоветская публичность: Беларусь, Украина (рp. 25-41). Вильнюс: ЕГу. Кримський, С. (2002). Газета як аналітика і вість. День, № 166, 13 вересня.

Кримський, С. (2003). Запити філософських смислів. Київ: ПАРАПАН.

Крымский, С. (2000). Философия как путь человечности и надежды. Киев: Курс

Махун, С. (2001). Сергій Кримський: «У нас не одне майбутнє, а багато, і минуле дає селекцію майбутнього". День, № 165, 14 вересня

Махун, С. Сюндюков, І. (2002). Сергій Кримський: «Принципи духовності XXI століття». День, № 210, 15 лист.

Матиенко, Г. (2004). Журналистика как философия. 2000, 12 нояб., Retrieved from http://www.2000. ua/v-nomere/svoboda-slova/ekspertiza_svoboda-slova/zhurnalistika-kak-filosofija_arhiv_art.htm

Сюндюков, І. (2007). Сергій Кримський про мистецтво житии. День, 13 липня

Пэнто, Л. (1996). Философская журналистика. В S/^'97. Социо-Логос постмодернизма (сc. 30-56), Москва: Институт экспериментальной социологии

Энговатова, А. (2007). Социальная онтология «новых философов». Социологическое обозрение, Том 6 , №า, 47-54. 